\title{
DIGITAL TECHNOLOGIES AS A DRIVER FOR THE DEVELOPMENT OF THE TOURISM INDUSTRY
}

\author{
Natalia Natocheeva ${ }^{1, *}$, Liliya Shayakhmetova ${ }^{2}$, Aigul Bekkhozhaeva ${ }^{3}$, Nazgul $^{2}$ \\ Khamikhan ${ }^{2}$, Dolores Pshembayeva ${ }^{4}$ \\ ${ }^{1}$ Plekhanov Russian University of Economics, 117997, Moscow, Russian Federation \\ ${ }^{2}$ L.N. Gumilyov Eurasian National University, 010008 Satpayev 2 Str., Nur-Sultan, \\ Kazakhstan \\ ${ }^{3}$ Korkyt Ata Kyzylorda State University, 29A Aiteke bie str, 120014 Kyzylorda, \\ Kazakhstan \\ ${ }^{4}$ Kazakh Humanitarian Law Innovative University, 071400, Semey, Kazakhstan
}

\begin{abstract}
The article deals with the development of digitalization in the field of tourism. The authors note the motives of the tourist market subjects to use digital technologies. It is pointed out that digitalization is a new form of communication between producers and consumers of tourist services, becoming a source of competitive advantages of tourist organizations. Special attention is paid to the importance of developing eco-tourism in the Republic as the most promising segment. The role of marketing for tourism development is highlighted, the characteristics of the marketing complex and its features for tourist activities are given. The most promising directions of digitalization in the field of tourism are considered. The SWOT analysis of Kazakhstan's tourism business is given. The study developed recommendations for using broad marketing opportunities for tourism development in the Republic of Kazakhstan.
\end{abstract}

Keywords: digitalization, digitalization of tourism, digital technologies in tourism, cluster, tourism market, marketing in tourism.

\section{INTRODUCTION}

The development of the economy in the modern world is connected with the digitalization of all its activities. The difference between the digital economy as a type of economic activity and the conventional economy is that the most important resource in the sphere of production, exchange and consumption, as well as distribution, will be information and methods of managing it. That is, information will acquire the character of the main assets of the enterprise, play a primary role in its economic activity.

The tourism sector, which is most active in the implementation of digital technologies, has not been left out of the process of digitalization. In the tourism sector, the

\footnotetext{
* Corresponding author: natocheeva12@yandex.ru
} 
use of new digital technologies is constantly expanding, they are becoming more accessible to everyone.

The widespread development of Internet of things technologies has a significant positive impact on the development of tourism business due to the fact that it makes it possible to accurately analyze the preferences of tourists, taking into account the places they visit. Internet of things technologies in the tourism industry include the emergence of such technical devices as geolocation bracelets, mobile guide apps, ticket payment apps, virtual reality technologies.

Modern software applications can quickly respond to the preferences of the tourist, assist in the search for a destination and perform an assessment of tourist attractions of the organization. Based on this information, you can analyze data about a tourist's profile, the objects they visit, the amount of time spent visiting tourist sites, and so on. With almost no special time and material costs for performing surveys of tourists and their statistical processing, you can use the Internet to analyze tourist preferences, anticipate their changes, and make sure that existing tourist offers match the needs of the client.

\section{LITERATURE REVIEW}

Digital marketing as a means of promoting a product or service has become an important part of the modern economy. Every major segment of the market is developing with the help of digital technologies, using them to increase sales, brand awareness, and create certain trends related to the company's or organization's activities. Tourism sees digital technologies as the shortest and most effective way to reach its goal. Since the end user can be thousands of kilometers away from their travel route digital promotion plays an important role in the tourism industry.[1]

"Today, 3.5 billion people have Internet access. This number includes people of all age groups, with different earnings and social status. This indicator is growing every year. If earlier it was believed that the Internet is mainly used by young people, now more and more adults and older people, especially abroad, use social networks every day and use the Internet to search for information, " said Dulat Iman, Director of the PR and Marketing Department of the national company Kazakh Tourism.

Arman Esenguzhinov, Director of the IT company for development: - to promote tourism in Kazakhstan, we need to use modern technologies with our rich history. Thus, to get a synergistic effect, so that foreign tourists can see and get full knowledge through a single portal, thereby solving the problem of information about our rich Kazakhstan. To improve perception with 360 elements is a presence effect, AR technologies are augmented reality.

"In social networks, all friends, those people with whom the user communicates and trusts them, are connected to each other in the same network. When a user posts a post about taking a vacation, their posts will be trusted more than the branded content. If a user is interested in a post and leaves a comment under it, their friends will see it and the information will spread further. Accordingly, with increased engagement, information in the network spreads even faster, " - said the chief Manager of the PR and marketing Department of NC "Kazakh Tourism" Marzhan Traispayeva.

Promotion of a destination, i.e., not individual companies, products or services, but an entire country or region as a tourist destination has its own characteristics. The most important thing in promotion is to create a good impression of the country. On a regular basis, you need to distribute information, a key message about the benefits of travel and recreation in the country, that this country has the features that the user wants to see, live and experience. 
"Accordingly, the main task for Kazakhstan at the moment is to create a positive image of Kazakhstan as a tourist destination and increase the interest of potential tourists to Kazakhstan. This will create and increase the demand for the services of tourist companies and hotels in Kazakhstan. Therefore, it is necessary to regularly distribute relevant key messages to the target audience and gradually improve the tourist image of the country",Iman Said.

\section{METHOD OF RESEARCH}

Let's consider the most promising areas of digitalization of tourism:

1) Marketing Complex. To promote tourist services, it is necessary to correctly use the socalled "marketing package" of services. The concept of "marketing complex" was first scientifically established in 1964 by Neil Borden, a Professor at the Harvard business school. The concept of "4P", first published in 1965 in the article" the Concept of the Marketing Mix", authored by Neil Borden, is that the marketing complex consists of four components: product( Product), price (Price), promotion of goods on the market (Promotion) and delivery of the product to consumers (Place). In the service industry, the familiar 4pmarketing model only starts working when you add three more " $\mathrm{P}$ " and transforms into the $7 \mathrm{P}$ marketing model, where you add company personnel( People), physical evidence (physical evidence), and process (Process). This refers to the level of development of service standardization and quality of services, modification of services and availability of "after-sales" service. Thus, in order to meet the tourist demand, it is necessary to have several elements. If one of them is missing, the strategic goal of tourism cannot be achieved. [2]

2) Online purchase of tours designed by tour operators. To develop the tourism sector in Kazakhstan, it is necessary to digitalize tourism. In the XXI century, digital tourism is developing in various forms, one of which is the online purchase of tours designed by tour operators. In the list of Internet resources that offer such services, you can name the search engine of the network of travel agencies "My burning tour", the search system for tours Avianta, the online store of tours Travelata.ru etc. Search engines position themselves as resources that allow you to search for suitable tours offered by a variety of tour operators on the basis of set criteria that take into account personal preferences and wishes of customers, find last-minute tours, monitor changes in prices for tours of interest in order not to miss the moment of making a transaction of purchase and sale of tourist products to the benefit of the consumer. [3]

3) Blockchain Technology. This technology involves finding data on purchases of tourist services in a single digital space, which can help each of the participants in the process of providing services for the implementation of a tourist product to focus on real information about consumers and anticipate their needs by personalizing advertising offers. As an example, Lufthansa has already started working with the blockchain startup WindingTree to implement and evaluate the effectiveness of decentralized applications for Amateur travel. In addition, one of the modern forms of digitalization of tourism is the development of mobile applications that are useful for tourist travel. For example, the application Yandex Maps and Google Maps provide users with the ability to build a route from one point to another using a personal vehicle, public transport or on foot, which is very convenient and useful when travelling in unfamiliar areas. [4]

4) Technical innovations. Such innovations can include: QR code, mobile guides and reference books, online services that contain information about guides and reference books, as well as virtual tours. The use of QR-code in excursion activities becomes really limitless. We believe that such an innovation should be equipped, first of all, with sights and 
monuments of architecture and culture of the city, in addition, this innovation is applicable to any Museum (Kazan Bulletin of young scientists 2019. Volume 3. No. 2163). The QR code can also be used when developing a quest tour, because this kind of tour involves a competitive nature and independent search for solutions, and a QR code in this situation would be the easiest way to get it. Based on the above, it can be noted that in recent years we have seen a trend of emergence and application of various innovative forms of organization of excursion activities. Thus, it is appropriate to use such forms of innovation as radio guide, QR Code, and quest tour. Using the possibilities of digital and innovative technologies will help to improve the quality and increase the competitiveness of services, excursion activities, as well as ensure proper profit in the tourist market of the city or region. [5]

Thus, the digitalization of tourism takes various forms of manifestation, which include online purchase of ready-made tours formed by tour operators, and the development and implementation of mobile applications, including for tourists, digitalization of Amateur tours through the creation of online schools for novice travelers, etc. In the future, the digitalization of tourism will be accompanied by further process of displacement from the tourist market traditional companies with offline offices, development of design tours in the parameters, individually specified by each individual customer and, therefore, competitive advantage will go to those tourist organizations, which will be the best way to implement a process of customization in the provision of tourism services to consumers, turning them from potential customers not just real, but in the loyal and, therefore, permanent, ensuring long-term survival based on consistently high profit and profitability indicators.[6]

One of the events held in Kazakhstan in connection with the digitalization of tourism is the "Visit of Akmola". The Nur Otan party held a joint meeting Of the public Council for business support at the Akmola regional branch and the regional party curatorial Commission for"technology development".

Digitalization opens up new opportunities and trends, penetrates into all areas of life, changes the ways of communication and organization of work, forms of education and leisure. In accordance with the action Plan for the development of the tourism industry of Akmola region for 2017-2019, in may 2017, the tourist information Center of the MFB "Visit of Akmola" was established» [7].

The main goal of "Visit Akmola" is to collect and disseminate information about the unique tourist potential of the region, as well as support new business structures in the field of tourism activities in the region and beyond. At the first stage of activity, a regional sub-brand was developed that actively promotes itself in the domestic and foreign markets. The second stage will focus on advertising the main regional products and further support for advertising and PR. Progress will be achieved with the use of modern digital technology. Special attention is paid to digital marketing. What is behind the digitalization of the tourism industry? This is a single tourist portal, a digital marketing campaign and the development of e-tourism (digitization of tourist resources with elements of gay friendliness; 3D visualization-3D models and the creation of additional reality applications).[8]

Akmola visit has developed a new Internet resource (www.visitaqmola.kz) about the tourist potential of the Akmola region in three languages. The Internet resource takes into account new trends in web design, non-standard content transfer and maximum convenience of using the resource by tourists using a widescreen image.

The site is equipped with a filter that allows the functional visitor to choose a suitable place, entertainment facilities, and location. Currently, graphic and text content is being downloaded, as well as the introduction of an interactive map that will help potential tourists with visual orientation in the territory of Akmola region.

The site allows users to track the development process of the site, easily find information about upcoming, planned and only tourist events on its pages; services in the field of tourism and related industries in the region; about the objects of the tourist industry 
in the region (attractions, museums, routes, hotels, restaurants, recreation centers, etc.) in the format of media packages; allows you to find information in most cases. [9]

Tourist information kiosks are installed in Astana-the international airport named after Nursultan Nazarbayev, in the village of Burabay-on the basis of the visit center of "Burabay Damu" LLP, and this is how the kiosk will look in Astana at the Nurly Zhol station. At the next stage, it is planned to place them in other cities of Kazakhstan and on the border with Russia. In this direction, we are also developing a mobile app for gadgets with the ability to read a QR code (from iOS and Android operating systems) from tourist sites with synchronization of the portal interface.[10]

As part of the digitization project, a large-scale guide-tourist portal was created in the Akmola region, which includes more than 50 attractions, 43 attractions in the region, and 25 tourist destinations (Kokshetau, Borovoe, Zerenda, Sandiktau, Korgalzhyn). It not only offers color and photo specifications, but also provides users with all the latest geolocation technologies, augmented reality, 3D rendering, booking, and more. [11]

Kazakhstan Lapland. "We have moved the concept of real Lapland, slightly reduced, compressed and added our national flavor. A person gets here as if in a fairy tale, and this attracts tourists. They want to see a real Santa Claus, ride a husky. The feature of the site is that winter entertainment is accumulated in one place. More than 30,000 people visited Kazakhstan's Lapland this winter, "- says Azamat Baymukanov, head of the Burabay-Damu unified contact center. LLP "Burabai Lady" carries out activities aimed at attracting tourists to the resort area Burabay. Since the beginning of 2018, BCCA has become a venue for dozens of different formats of events: festivals, bicycles, horse racing, shooting TV projects, concerts, etc.to attract tourists and maximize the stay of tourists in the Shchuchinsk-Borovoye resort area, an ethnographic village "Zhailau" in the field of maral economy was opened, where you can get acquainted with the history, culture, life, traditions and cuisine of the Kazakh people. The possibility of functioning of the ethnic browser "Zhailau" is considered throughout the year. It is also preparing to start construction of the resort "AK Bura" in the framework of a project developed by the Spanish company THR, between lake Bolshaya Shabakty and lake Tekekol in BCPC.[12]

The resort has a rating of $4+$ and is focused on active and family holidays. The main concept of the new resort, along with comfortable living conditions, is a wide range of entertainment and recreation. It is assumed that "AK Bura" will not only increase the influx of tourists to the Borovsky district, but also reduce the load on the village of Burabay.[13]

The decision to move to a new country can be a long process. Seeing the footage, photos, reading a book, listening to the story of a colleague or friend, a potential tourist is inspired and dreams of traveling.[14] The tourist Will then be able to purchase the tour online, and upon arrival in the country will continue to search for the necessary information on the Internet, as well as share photos and effects on social networks and leave comments on tourist sites. Thus, the tourist goes through all five stages of the trip: inspiration, planning, booking, travel (display) and the period after the trip (publication of impressions). [15]

Accordingly, digital marketing should cover all stages of travel: from inspiration to buying a tour or booking a hotel, and then inspiration to return home and return to the country.[16]

Digital marketing is an effective way to attract the attention of your customers, including because Internet publications are primarily attractive to users and are not advertising. 
Moving is undesirable. Instead of open advertising, brands interact with potential customers. Emotions and communication with potential tourists is a viable social network.[17]

In addition, the advantages of digital marketing are that the target audience for your ad is selected based on strictly defined criteria, and you have access to demanding markets around the world without huge costs.[18]

The tourism industry in Kazakhstan should become a powerful sector of the national economy. As foreign practice shows, the development of this industry will be possible if the state authorities are aware of the importance of the role of tourism business in the socioeconomic development of the Republic of Kazakhstan and begin to pursue a protectionist policy regarding the tourism industry, as well as pay great attention to the training of specialists in the tourism industry.

State support is the most important factor in the development of tourism. Only the optimal combination of state incentives and effective work of national tourism companies can promote Kazakhstan's tourism product to foreign markets.[19]

The development of tourism in the country depends primarily on the development of an educated and skilled workforce. That is why, in order to create the necessary skilled labor force and on-the-job, it is necessary to open professional courses, it is necessary to plan training to improve the skills of the existing tourist workforce. The activity must be designed to increase the tourist awareness of both real and legal entities.

It is obvious that published academic research and open discussion on the development of tourism in Russia would be very useful for Kazakhstan.

The biggest problem of tourism in Kazakhstan is "insufficient demand". This can be explained by a lack of effective marketing. In particular, the countries of the region should develop a common marketing strategy.

For Kazakhstan, an innovative image strategy and product development, special marketing should be initiated, and pricing and security rules should be developed.

Especially we should go for a media blitz towards target countries on written and visual media, as well as online media and bulletins. Tax incentives should be applied to foreign travel agencies, airlines and banks, and their payments should be guaranteed by the state.

Conditions at the airport and visa procedures should be simplified for foreign tourists, airport staff should be selected from among persons who speak foreign languages and have a tourist consciousness.

Below is a SWOT analysis of Kazakhstan's tourism business. (Tab.1)

Table 1 -SWOT analysis of Kazakhstan's tourism business

\begin{tabular}{|l|l|}
\hline \multicolumn{1}{|c|}{ Strength } & \multicolumn{1}{|c|}{ Weakness } \\
\hline -stable political situation; & - undeveloped tourism infrastructure for \\
- hospitality of the Kazakh people; & the development of inbound tourism; \\
- state support; & -high cost and low availability of external \\
- tourist recreational resources; & capital; \\
- stable market competition; & -high cost of participation in fairs; \\
- satisfactory performance & - lack of interaction with domestic and \\
\hline \multicolumn{1}{|c|}{ Opportunities } & foreign databases \\
\hline
\end{tabular}


- Kazakhstan's accession to the WTO;

- support for the development of tourist regions;

- support for the development of medium and small enterprises;

- attracting new financially wealthy groups of clients;

- development of competition
- introduction of new regulations;

- entry of new foreign companies into the tourist market;

-competition;

- low barriers to entry;

- continuous and long-term reduction in profitability

Marketing research of the tourist services market creates a basis for effective use of the country's territorial potential, since initially marketing research in tourism is aimed not only at studying the demand and identifying its potential customers, but also at forming the demand itself, taking into account the development and use of the existing tourist potential of certain territories.

To assess the attractiveness of tourism in Kazakhstan, data from marketing research conducted by the international company IPK were used.

Based on the conducted research, segments of foreign consumers were identified by socio-demographic factors, which are presented as follows: English $-10 \%$ of the total tourist flow in Kazakhstan, age - from 35 to 54 years, secondary and higher education, 26 $\%$ - family; the second group - Koreans make up $8 \%$ of the flow of tourists, age-from 25 to 54 years, higher education, $39 \%$ - married couples; group 3-French - $6 \%$ of the flow of tourists, age-from 25 to 54 years, secondary and higher education, $32 \%$ of married couples; 4 group-Germans, age-from 35 to 54 years, higher and secondary education, $24 \%$ - married couples; 5 group-Japanese - $1 \%$ of the flow of tourists, age- $45-65$ years, higher education, married couples make up $10 \%$.

Consumer preferences of foreign tourists based on IPK research are shown in the figure 1.

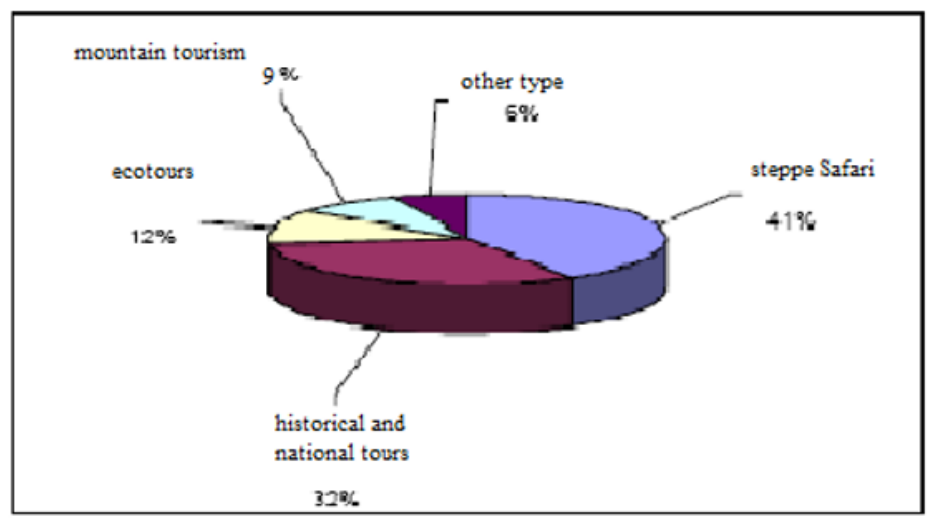

Fig. 1 - Preferences of foreign tourists by type of tourism in Kazakhstan

As can be seen from the data presented, the greatest interest among foreign consumers is steppe Safari, namely jeep rides on the steppes and national hunting. For this type of tourism in Kazakhstan, there are 20 landscape zones represented by steppes with salt and fresh lakes. Based on the analysis of secondary data, the following conclusions are made: to attract foreign tourists to Kazakhstan, there are all the necessary resources and certain 
infrastructure. Taking into account the rating of foreign tourists ' interest in the types of tours, we can conclude that Kazakhstan is provided with resources for the most popular steppe Safari tourism, but at the same time there is a low level of infrastructure development. Even in the absence of infrastructure, the organization of travel and attracting foreign tourists is possible, since it does not require large financial investments.[20]

\section{CONCLUSION}

The process of digitalization of the tourism industry will help to increase its competitiveness, since customers will have a better quality of service, and tourism service companies will receive higher revenues from their activities. Thus, under the influence of digital transformation, important trends have emerged in the tourism industry at the present time. Using the opportunities of innovative and digital technologies in the field of tourism has a positive impact on making the tourism industry more competitive in the modern digital world.

\section{REFERENCES}

1. Ziyadin, S., Koryagina, E., Grigoryan, T., Tovma, N., Ismail, G.Z. International Journal of Civil Engineering and Technology, 10(1), 998-1010 (2019).

2. Ziyadin, S., Suieubayeva, S., Kabasheva, N., \& Moldazhanov, M. Economic Annals -XXI, 163(1-2), 35-40. (10) (2017). DOI: 10.21003/ea.V163-07

3. Beyzhanova, A., Mamyrbekov, A., Umarov, I., Orazymbetova, A., Khairullaeva, A. E3S Web of Conferences (2019). DOI: 10.1051/e3sconf/201913504023

4. Watkins, M., Ziyadin, S., Imatayeva, A., Kurmangalieva, A., Blembayeva, A. Digital tourism as a key factor in the development of the economy. Economic Annals-XXI, 169(1-2), 40-45 (2018).

5. Daribaeva A.K, Shulenbaeva F.A Aktualnye voprosy razvitiya turizma v respublike Kazahstan. Ekonomika i biznes teoriya i praktika(5), 208-212, (2016).

6. Ziyadin, S., \& Takhtaeva, R. Trends and problems in tourism development on the territory of Eastern Kazakhstan region. Actual Problems of Economics, , (9), 232236. (2014).

7. Ziyadin, S., Litvishko, O., Dubrova, M., Smagulova, G., Suyunchaliyeva, M. Diversification tourism in the conditions of the digitalization. International Journal of Civil Engineering and Technology. 10(2), 1055-1070 (2019).

8. Ziyadin, S., Madiyarova, A., Blembayeva, A. International tourism as a factor of world development, Proceedings of the 32nd International Business Information Management Association Conference, IBIMA 2018 - Vision 2020: Sustainable Economic Development and Application of Innovation Management from Regional expansion to Global Growth, Pages 5846-5853 (2018).

9. Shedenov, U., Litvishko, O., Kazbekov, B., Suyunchaliyeva, M., Kazbekova, K. Improvement of ecological tourism on the principles of sustainable economic development E3S Web of Conferences 2019.

10. Garifyanova Vilena I., \& Galimov Almaz Mirzanurovich. Issledovanie vozmozhnostej cifrovizacii $\mathrm{v}$ industrii mezhdunarodnogo turizma. Kazanskij vestnik molodyh uchyonyh, 3 (2 (10)), 157-164 (2019).

11. Ivanova N.I. Nacionalnye innovacionnye sistemy. M.: Nauka (2009).

12. Kalashnikov A.S. Kak avtomatizirovat rabotu turisticheskogo agentstva .Turinfo 10(2) (2010).

13. Lisenko A.A. Vyzovy i vozmozhnosti cifrovoj epohi;socikulturnyj aspekt Rossijskij gumanitarnyj zhurnal 3(7) 217-222(2018). 
14. Saak, A. E. Menedzhment v socialno-kulturnom servise i turizme. M.: Piter, 512(4) (2017).

15. Solovev, S. S. Bezopasnyj otdyh i turizm.M.: Academia, 8(5) - 288 (2017).

16. Chudnovskij, A. D. Informacionnye tehnologii upravleniya v turizme.M.: KnoRus, 104 (2014).

17. Aleeva V.A., Mochalova Yu.D. Primenenie sovremennyh informacionnyh tehnologij v upravlenii biznesom v sfere turizma. Biznes-obrazovanie v ekonomike znanij. 3(3) (2018).

18. Gerchikova E.Z., Spiridonova E.P. Sociologicheskie aspekty transformacii sfery rekreacii i turizma v usloviyah cifrovoj ekonomiki. Vestnik Saratovskogo gosudarstvennogo socialno-ekonomicheskogo universiteta.3 (72).185-189 (2018).

19. Danilova N.F., Saraeva I.V. Globalnoe cifrovoe prostranstvo: perspektivy i ugrozy dlya ekonomicheskogo razvitiya stran.Izv.Sarat.un-ta.Nov.ser. Ser. Ekonomika. Upravlenie. Pravo. 19(1) 65-73 (2019).

20. Ziyadin, S., Doszhan, R., Saparova, G., Omarova, A., Proceedings of the 32nd International Business Information Management Association Conference, IBIMA 2018 - Vision 2020:, Pages 3379-3383 (2018). 